DOI: $10.1590 / 1089-6891 v 17 i 425039$

VETERINARY MEDICINE

\title{
EVALUATION OF Salmonella pullorum SHEDDING IN JAPANESE QUAILS (Coturnix coturnix)
}

\section{AVALIAÇÃO DA DISSEMINAÇÃO DE Salmonella pullorum EM CODORNAS JAPONESAS (Coturnix coturnix) INFECTADAS EXPERIMENTALMENTE}

\author{
Roberta Cristina da Rocha-e-Silva ${ }^{1^{*}}$ \\ William Maciel Cardoso ${ }^{1}$ \\ Adonai Aragão Siqueira ${ }^{1}$ \\ Régis Siqueira de Castro Teixeira ${ }^{1}$ \\ Átilla Holanda Albuquerque ${ }^{1}$ \\ Ruben Vasconcelos Horn ${ }^{1}$ \\ ${ }^{1}$ Universidade Estadual do Ceará, Fortaleza, CE, Brasil. \\ *Autora para correspondência - robertarochavet@hotmail.com
}

\begin{abstract}
Salmonella Pullorum is a pathogen that infects several species of birds, mainly offspring, and among them, quails. Therefore, this study was performed in order to evaluate the $S$. Pullorum shedding in experimentally infected Japanese quails (Coturnix coturnix) and egg contamination ability. S. Pullorum ATCC lyophilized was inoculated in all birds (60 quails at 160 days). Before the inoculation, rapid slide agglutination test was performed in all birds and individual cloacal swabs were collected randomly. Birds from group A and group B received $0.5 \mathrm{~mL}$ of inoculum containing $1.5 \times 10^{2} \mathrm{CFU}$ and $7.5 \times 10^{8} \mathrm{CFU}$ of $S$. Pullorum, respectively, directly in the crop. The cloacal swab samples were collected on 3, 6, 9, 16 and 23 days post-inoculation (dpi) and all eggs were collected. Positive cloacal swab samples were initiated at the $3^{\text {rd }}$ dpi. A total of 30 pool of eggs was analyzed, of which $73 \%$ positive for $S$. Pullorum until the $16^{\text {th }}$ dpi. In conclusion, adult Japanese quails are possibly more resistant to the infection by $S$. Pullorum, but they can shed this pathogen in the environment as well.
\end{abstract}

Keywords: egg; infection; inoculation; Japanese quails.

\section{Resumo}

Salmonella Pulllorum é um patógeno que acomete várias espécies de aves, principalmente jovens, dentre essas, codornas. Dessa forma, o estudo teve como objetivo avaliar a eliminação da $S$.Pullorum em codornas japonesas (Coturnix coturnix) infectadas experimentalmente, bem como avaliar a capacidade de contaminação dos ovos. Foi utilizada uma cepa de $S$. Pullorum ATCC liofilizada para inoculação de todas as aves (60 codornas com 160 dias de idade). Antecedendo a inoculação, foi realizado exame de Soroaglutinação Rápida em Placas em todas as aves e coletados suabes cloacais individuais de aves escolhidas aleatoriamente. As aves do grupo A e do grupo B foram inoculadas, com $0,5 \mathrm{~mL}$ do inóculo contendo $1.5 \times 10^{2}$ UFC e $7.5 \times 10^{8}$ UFC, respectivamente, diretamente no papo. As coletas de suabes cloacais ocorreram nos dias 3, 6, 9, 16 e 23 pós-inoculação e todos os ovos foram coletados. Amostras positivas de suabes cloacais se iniciaram aos 03 dpi. Foi analisado um total de 30 pool de ovos, sendo $73 \%$ positivos para $S$.Pullorum até 16 dpi. Conclui-se dessa forma que possivelmente codornas japonesas adultas são mais resistentes a infecção por $S$.Pullorum, mas pode disseminar o agente ao meio ambiente.

Palavras-chave: Codorna japonesa; infecção; inoculação; ovos. 
Enviado em: 24 junho de 2013.

Aceito em: 19 setembro de 2016.

\section{Introduction}

Salmonella causes diseases that affect the poultry industry. Among them, Pullorum disease, caused by Salmonella enterica subsp. enterica serovar Pullorum; fowl typhoid, caused by S. Gallinarum; and fowl paratyphoid, caused by any remaining serotype of Salmonella ${ }^{(1)}$.

Salmonella Pullorum causes a disseminated systemic infection in birds ${ }^{(2)}$, mainly young birds ${ }^{(3)}$. Pullorum disease stands out for its high economic cost to poultry production and, despite the low risk of infection, the surveillance program for $S$. Pullorum should be reliable ${ }^{(4)}$.

$S$. Pullorum can be vertically transmitted to chicks due to the location in the reproductive tract. The bacteria may also persist in the reproductive system and spleen of chickens for more than 40 weeks post-infection and can further expand horizontally in hatchery facilities ${ }^{(3)}$.

According to Shivaprasad ${ }^{(5)}$, several bird species are susceptible to pullorum disease, such as quails, pheasants, ducks, among others. Only a few differences in the susceptibility between them have been reported ${ }^{(6)}$. Mortality rates are very similar to that of chickens and turkeys ${ }^{(6)}$.

As the quail production ascends in the poultry market, both egg and meat businesses, special care to the specific health conditions concerning the National Program of Poultry Health (PNSA) becomes essential. Thus, this study was performed to evaluate the $S$. Pullorum shedding in Japanese quails (Coturnix coturnix) experimentally infected, and to assess the egg contamination.

\section{Material and Methods}

We used a strain of Salmonella enterica subsp. enterica serovar Pullorum ATCC lyophilized and stored at $-20{ }^{\circ} \mathrm{C}$, acquired from the Oswaldo Cruz Institute/RJ. The $S$. Pullorum was prepared in saline solution at $0.85 \%$, then plated on nutrient agar and incubated at $37^{\circ} \mathrm{C} / 24 \mathrm{~h}$ for preparation of the inoculum.

A single colony was removed from the nutrient agar and transferred to a test tube containing $10 \mathrm{~mL}$ of tryptic soy broth (Acumedia Manufacture, Inc. Lansing, Michigan, USA), which was incubated at $37^{\circ} \mathrm{C}$ for 24 hours. After this period, $0.1 \mathrm{~mL}$ of this suspension was subjected to eight serial dilutions $\left(10^{-1}\right.$ to $\left.10^{-8}\right)$ containing $10 \mathrm{~mL}$ of tryptic soy broth. Of each tube, $0.1 \mathrm{~mL}$ was plated on brilliant green agar (BGA) (Oxoid Ltd., Basingstoke, Hampshire, England) containing $20 \mu \mathrm{g} / \mathrm{mL}$ of novobiocin (NOV) (Sigma Chemical Co., St. Louis, MO, USA) and spread with Drigalski handle. These plates were incubated in a bacteriological incubator at $37^{\circ} \mathrm{C} / 24 \mathrm{~h}$ and, after this period, the Colony Forming Units (CFU) were quantified and the concentration of each tube determined. Given the CFU's, two inocula were prepared with different concentrations $\left(1.5 \times 10^{2} \mathrm{UFC}\right.$ and $\left.7.5 \times 10^{8} \mathrm{UFC}\right)$ of Salmonella Pullorum.

A total of 60 quails (Coturnix coturnix) at 160 days were used. The birds were housed in the experimental facilities of the Laboratory of Ornithological Studies (LABEO), State University of Ceará (UECE). Birds were divided into two groups (A and B) in cages measuring $20 \times 15 \times 15 \mathrm{~cm}$, with four quails per cage. Birds received feed and natural mineral water ad libitum throughout the experiment. The local ethics committee approved this study under the registry number: 08627875-4.

Rapid Slide Agglutination Test (RSAT) was performed in all birds and 21 individual cloacal swabs were collected from randomly selected birds for bacteriological examination three weeks prior to 
inoculation.

Birds in group A and group B were inoculated with $0.5 \mathrm{~mL}$ of inoculum containing $1.5 \times 10^{2} \mathrm{CFU}$ and $7.5 \times 10^{8} \mathrm{CFU}$, respectively, orally through a $500 \mu \mathrm{L}$ micropipette attached to an urethral tube.

On the $3^{\text {rd }}, 6^{\text {th }}, 9^{\text {th }}, 16^{\text {th }}$, and $23^{\text {rd }}$ post-inoculation day, individual cloacal swabs were performed on all birds, totaling 300 samples, and eggs were collected aseptically with procedure gloves. Each pool of ten eggs corresponded to a sample, totaling 30 samples throughout the experiment.

The bacteriological procedure was performed according to the methodology adopted by Pinheiro et al. ${ }^{(7)}$, as follows: swab samples were transferred to tubes containing $9 \mathrm{~mL}$ of selenite-cystine broth (EM Science, Merck, Darmstadt, Germany) and incubated at $37^{\circ} \mathrm{C} / 24 \mathrm{~h}$. After this period, they were plated on brilliant green agar with Novobiocin $(20 \mu \mathrm{g} / \mathrm{mL}$ ) (AVB-Nov) and again returned to the bacteriological incubator for 24 hours at $37^{\circ} \mathrm{C}$. Triple sugar iron agar slants (EM Science, Merck, Darmstadt, Germany), lysine iron agar slants (Oxoid Ltd., Basingstoke, Hampshire, Engalnd), and semi-solid SIM medium (sulfide, indole, and motility) (Oxoid Ltd., Basingstoke, Hampshire, England) were used for biochemical identification. Subsequently, the samples were confirmed by serological tests with antiserum somatic "O" and flagellar " $\mathrm{H}$ " (Difco Laboratories, Becton Dickinson Microbiology Systems, Sparks, Maryland, USA).

From each egg sample, composed by a pool of 10 eggs (eggshell and egg internal content) crushed in a sterile beaker, an aliquot of $1 \mathrm{~mL}$ was transferred to selenite-cystine broth (Oxoid Ltd., Basingstoke, Hampshire, England) and microbiological procedures were performed as described previously.

The frequency data for Salmonella isolation on swabs were compared by chi-square, and egg samples by Fisher's exact test. All data were subjected to a significance level of 5\%.

\section{Results}

The rapid slide agglutination test was negative in all birds. There was no isolation of Salmonella spp. from cloacal swabs of any birds sampled before the start and no mortality throughout the experiment.

Group A showed significant difference in isolation on the $6^{\text {th }}, 9^{\text {th }}$, and $16^{\text {th }}$ dpi with the highest number of positive samples compared to $3^{\text {rd }}$ and $23^{\text {rd }}$ dpi. However, group B showed no significant difference between days post-inoculation.

The frequency of positive samples isolated from cloacal swabs was high on the $3^{\text {rd }} \mathrm{dpi}$, and the isolation rate was statistically higher in group B when compared to group A (Table 1). On the $6^{\text {th }}, 9^{\text {th }}$, $16^{\text {th }}$, and $23^{\text {rd }}$ dpi there was no significant difference between the groups.

Table 1. Absolute and relative frequency of $S$. Pullorum isolation from swabs of Japanese quails after sampling on days $3,6,9,16$ e 23 post-inoculation

\begin{tabular}{cccccc}
\hline \multirow{2}{*}{$\begin{array}{c}\text { Experimental } \\
\text { Groups }\end{array}$} & \multicolumn{5}{c}{ Days post-inoculation } \\
\cline { 2 - 6 } & $\mathbf{3}$ & $\mathbf{6}$ & $\mathbf{9}$ & $\mathbf{1 6}$ & $\mathbf{2 3}$ \\
\hline $\mathrm{A}$ & $8(26.7 \%)^{\mathrm{Bbc}}$ & $12(40.0 \%)^{\mathrm{Aab}}$ & $15(50.0)^{\mathrm{Aa}}$ & $9(30.0)^{\mathrm{Aabc}}$ & $5(16.7)^{\mathrm{Ac}}$ \\
$\mathrm{B}$ & $15(50.0 \%)^{\mathrm{Aa}}$ & $11(36.7 \%)^{\mathrm{Aab}}$ & $14(46.7)^{\mathrm{Aa}}$ & $8(26.7)^{\mathrm{Aa}}$ & $10(33.4)^{\mathrm{Aa}}$ \\
\hline
\end{tabular}

$A B C-$ Capital letters indicate significant difference $(p>0.05)$ between treatments

$a b c-$ Small letters indicate significant difference $(p>0.05)$ between days post-inoculation of the same treatment. 
Thirty egg samples were analyzed. Of these, 22 were positive for $S$. Pullorum until the $16^{\text {th }}$ dpi. There was no significant difference between the groups because all the samples were positive on the $3^{\text {rd }}$ and $6^{\text {th }}$ dpi. A $50 \%$ decrease of positive egg samples on the $9^{\text {th }}$ dpi was observed, while on the $23^{\text {rd }}$ dpi all the samples were negative (Figure 1).

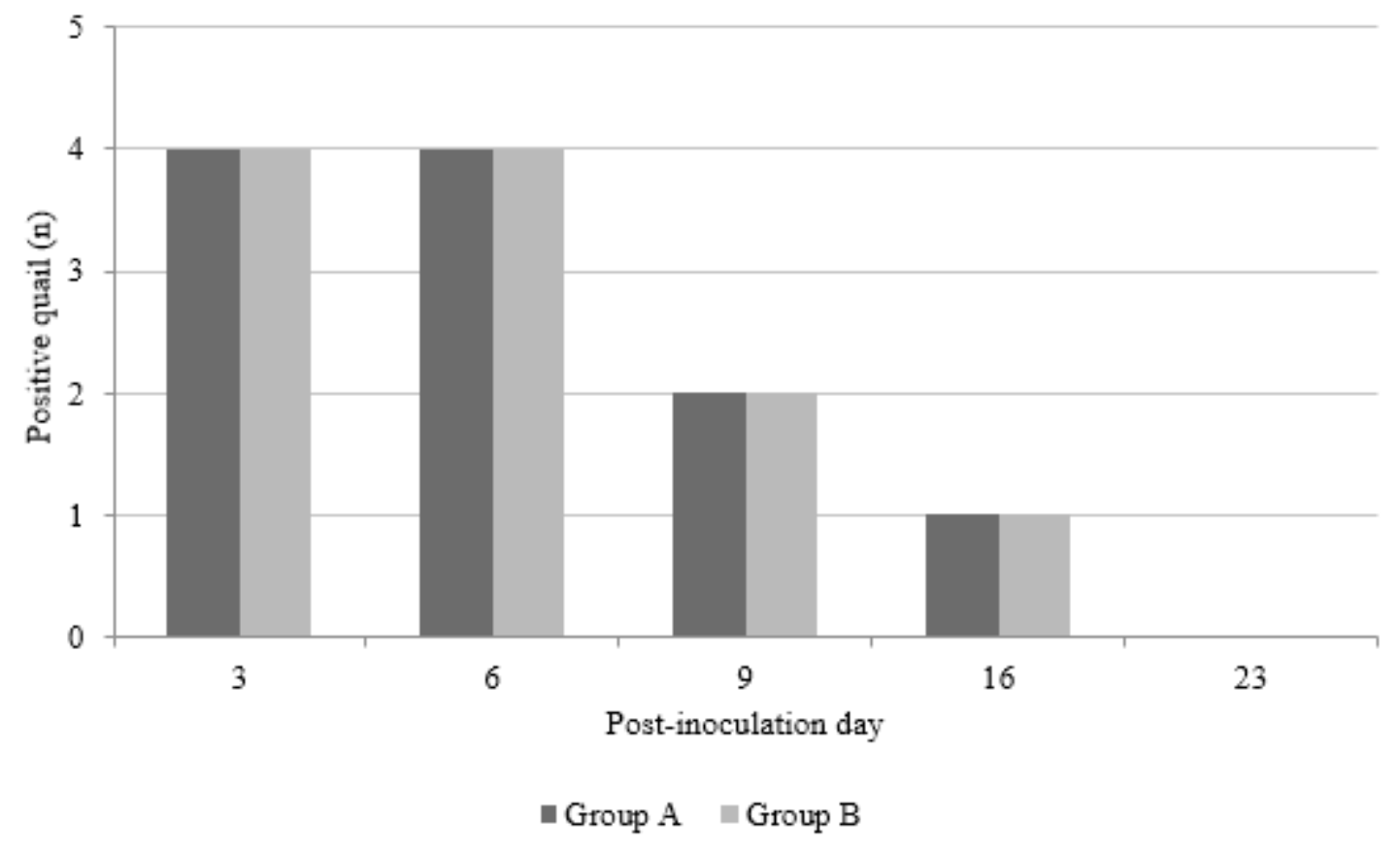

Figure 1. Absolute and relative frequency of $S$. Pullorum isolation from egg samples of groups A and $B$.

\section{Discussion}

No inoculated birds showed clinical symptoms, unlike the results obtained by Buchholz \& Fairbrother ${ }^{(6)}$, in which the bobwhite quails (Colinus virginianus) presented difficulty breathing, head drawn down, eyes closed, drooping wings, anorexia, weight loss and profuse white diarrhea after four days of infection. Pinheiro et al. ${ }^{(7)}$ observed brown chickens inoculated with $S$. Pullorum showed clinical signs characterized by drowsiness, weakness, loss of appetite, and drooping wings after four weeks, but there was no mortality and all birds recovered completely, while white chickens showed no symptoms. This demonstrates some birds have greater resistance to infection by Salmonella Pullorum and asymptomatic carriers can spread to other birds.

According to Calenge et al. ${ }^{(8)}$, commercial varieties of chicken are very homogeneous concerning production, but they are not homogeneous for disease resistance; therefore, resistance to salmonellosis and carrier state varies with strain and age. The resistance or susceptibility of carrier status in both age groups (young and adult) and in all organs varies according to the genotypic characteristics of the $\operatorname{bird}^{(9)}$.

No mortality was observed in the groups inoculated with Salmonella Pullorum throughout this experiment, in agreement with the study by Berchieri Jr. et al. ${ }^{(10)}$, who used the White Leghorn chicken strain, and observed no mortality on birds inoculated with $10^{9} \mathrm{CFU}$ 's of $S$. Pullorum during 
the experiment. Buchholz \& Fairbrother ${ }^{(6)}$ reported high mortality on 10-day-old quails infected by $S$. Pullorum with the concentration of $10^{3}$ and $10^{10}$, reaching at the end of the experiment (14 days) $75 \%$ mortality. Pourciau \& Springer ${ }^{(11)}$ also reported $50 \%$ mortality on bob white quails at three weeks of age inoculated with paratyphoid salmonellae $\left(1 \times 10^{7}\right.$ and $\left.5 \times 10^{6}\right)$. The birds used in this experiment were not young, which may have contributed for a reduction in mortality, since the disease affects more severely young birds.

In this experiment, higher shedding of $S$. Pullorum was observed in cloacal swabs from the $3^{\text {rd }}$ to the $9^{\text {th }}$ dpi in both groups. Buchholz \& Fairbrother ${ }^{(6)}$ also isolated it from cloacal swabs on the first few days post-infection $\left(6^{\text {th }} \mathrm{dpi}\right)$ from bobwhite quails inoculated with $S$. Pullorum. Pourciau $\&$ Springer ${ }^{(11)}$ found positive quails inoculated with $S$. Braenderup at 53 days post-inoculation. Wigley et al. ${ }^{(3)}$ observed that chickens inoculated with $S$. Pullorum had negative cloacal swabs. Berchieri Jr. et al. ${ }^{(10)}$ showed isolation of $S$. Pullorum in laying hens from four days post-inoculation until the end of the experiment (21 weeks of age). The presence of Salmonella in fecal samples of challenged chickens may be dose dependent. According to Ishola ${ }^{(12)}$, birds that received the largest inoculum of $S$. Enteritidis $\left(1.3 \times 10^{8} \mathrm{CFU}\right.$ 's $\left./ \mathrm{mL}\right)$ were able to excrete the bacteria for longer when compared to birds that received lower inoculum $\left(1.3 \times 10^{4} \mathrm{CFU}\right.$ 's $\left./ \mathrm{mL}\right)$, demonstrating that the oral dose has significant effects on important parameters in Salmonella infection ${ }^{(13)}$.

Contaminated eggs were found until the $9^{\text {th }} \mathrm{dpi}$, which differs from the results found by Berchieri Jr. et al. ${ }^{(14)}$, where 4-days-old birds inoculated with $S$. Pullorum persisted shedding in eggs until 21 weeks of age. According to Jones et al. ${ }^{(15)}$, the bird age may affect the integrity of the eggshell, reducing the quality and contributing to the microorganism penetration into the egg.

The infection affected the production of eggs. At the beginning of this experiment, the production was approximately $80 \%$, and suffered a reduction of $40 \%$. Barrow \& Lovell ${ }^{(16)}$ observed that hens at 40 weeks of age inoculated intraperitoneally with $S$. Enteritidis, also lowered the production by $10.5 \%$ within two weeks after infection, whereas oral infection in chickens at 24 weeks of age had no effect on egg production.

In a study performed by Wigley et al. ${ }^{(3)}$ with a total of 1,243 eggs of hens experimentally infected with $S$. Pullorum resulted in 81 positive eggs $(6.5 \%)$. In addition, the pathogen was present in follicles, developing eggs and ovarian tissue, which indicates that vertical transmission occurred through the infection of eggs in development. Salmonella can penetrate through the eggshell and associated membranes leading to contamination of chicks in the hatchery ${ }^{(17)}$, being the contamination of eggs of unvaccinated birds quite high during the three weeks after oral inoculation of $S$. Pullorum ${ }^{(18)}$.

Pinheiro et al. ${ }^{(7)}$ reported a reduced number of infected eggs (1\%) from chickens inoculated with $1.2 \times 10^{8} \mathrm{CFU}$ 's / $\mathrm{mL}$ of $S$. Pullorum for nine months. Berchieri Jr. et al. ${ }^{(14)}$ noted that for six weeks following the experimental infection with $10^{6} \mathrm{CFU}$ 's of $S$. Enteritidis to commercial strain chickens, 360 eggs were tested and none was positive, with low isolation from the liver, spleen, caeca, and ovarian interstitial tissue. After the invasion and colonization of the ovary and oviduct tissues, it is possible that species of the genus Salmonella are incorporated to the internal components of the egg during the formation, causing the production of contaminated eggs ${ }^{(19)}$.

\section{Conclusion}

Given the results of this study, we suggest that adult Japanese quails are more resistant to infection by $S$. Pullorum than commercial hens. In addition, they may function as asymptomatic carriers, eliminating the bacteria in the environment through the feces, infecting other birds, as well as their own progeny, through eggs. Therefore, establishing strict programs of surveillance, control and eradication of $S$. Pullorum in quails is of great importance to prevent the spread and contamination of products. 


\section{References}

1. Lax AJ, Barrow, PA, Jones PW, Wallis TS. Current Perspectives in Salmonelosis. British Veterinary Journal, 1995;151(4):351-377.

2. Holt PS, Chaubal LH. Detection of motility and putative synthesis of flagellar proteins in Salmonella Pullorum cultures. Journal of Clinical Microbiology, 1997;35(4):1016-1020.

3. Wigley P., Berchieri JR., A, Page KL, Smith AL, Barrow PA. Salmonella enterica serovar Pullorum persists in splenic macrophages and in the reproductive tract during persistent, disease-free carriage in chickens. Infection and immunity, 2001; 69(12):7873-7879.

4. Proux, K, Humbert, F, Jouy, E, Houdayer, C, Lalande, F, Oger, A, SALVAT, G. Improvements required for the detection of Salmonella Pullorum and Gallinarum. The Canadian Journal of Veterinary Research, 2002; 66(3):151-157.

5. Shivaprasad, H.L. Fowl typhoid and pullorum disease. Revue Scientifique et Technics, 2000;19(9)2:405424.

6. Buchholz, P.S, Fairbrother, A. Pathogenicity of Salmonella Pullorum in northern bobwhite quail and mallard ducks. Avian Diseases, 1992;36(2):304-31,.

7. Pinheiro LAS, Oliveira GH, Berchieri JR., A. Experimental Salmonella enterica serovar Pullorum infection in two commercial varieties of laying hens. Avian Pathology, 2001;30(2):129-133.

8. Calenge F, Kaiser P, Vignal A, Beaumont C. Genetic control of resistance to salmonellosis and to Salmonella carrier-state in fowl: a review. Genetics Selection Evolution, 2010;42:1-11.

9. Beaumont C, Chapuis H, Protais J, Sellier N, Menanteau P, Fravalo P, Velge P. Resistance to Salmonella carrier state: selection may be efficient but response depends on animal's age. Genetics Research Cambridge, 2009;91(3):161-169.

10. Berchieri JR., A, Murphy, C. K, Marston, K, Barrow, P. A. Observations on the persistence and vertical transmission of Salmonella enterica serovars Pullorum and Gallinarum in chickens: effect of bacterial and host genetic background. Avian Pathology, 2001a;30(3):221-231.

11. Pourciau SS, Springer WT. Frequency and duration of paratyphoid organism shedding by experimentally infected bobwhite quail (Colinus virginianus). Journal of Wildlife Diseases, 1978;14(2):203-207.

12. Ishola OO. Effects of challenge dose on faecal shedding of Salmonella Enteritidis in experimental infected chickens. African Journal of Biotechnology, 2009;8(7):1343-1346.

13. Gast RK, Guraya R, Guard J, Holt PS. Frequency and magnitude of internal organ colonization following exposure of laying hens to different oral doses of Salmonella Enteritidis. International Journal of Poultry Science, 2011;10(4):325-331.

14. Berchieri JR., A, Wigley, P, Page, K, Murphy, C. K, Barrow, P. A. Further studies on vertical transmission and persistence of Salmonella enterica serovar Enteritidis phage type 4 in chickens. Avian Pathology, v.30, n.4, p.297-310, $2001 b$.

15. Jones DR, Anderson KE, Curtis PA, Jones FT. Microbial contamination in inoculated shell eggs: I. effects of layer strain and hen age. Poultry Science, 2002;81(5):715-720,.

16. Barrow PA, Lovell MA. Experimental infection of egg-laying hens with Salmonella Enteritidis phage type 4. Avian Pathology, 1991;20(2):335-348.

17. Befungi ME, Cox NA, Frank JE, Buhr RJ. Bacterial penetration of the eggshell and shell membranes of 
the chicken hatching egg: a review. Poultry Science, 1999;8(4):499-504.

18. Okamura M, Tachizaki H, Kubo T, Kikuchi S, Suzuki A, Takehara K, Nakamura M. Comparative evaluation of a bivalent killed Salmonella vaccine to prevent egg contamination with Salmonella enterica serovars Enteritidis, Typhimurium and Gallinarum biovar Pullorum using 4 different challenge models. Vaccine, 2007;25(25):4837-4844.

19. Takata T, Liang J, Nakano H, Yoshimura Y. Invasion of Salmonella Enteritidis in the tissues of reproductive organs in laying japanese quail: An immunocytochemical study. Poultry Science, 2003;82(7):1170-1173. 